sailed up to the edge of the earth and discovered the earth had no edge after all. I imagine them clinging to the rails, shutting

their eyes and laughing when they found themselves floating instead of falling.

They went on sailing.

We went on talking. "A little farther," you said, and I went on.

We ran our hands along the seam.

You stared at me thinking if only you looked hard enough, it would all come clear.

I walked out.

I came back.

You said, "Let's talk about it."

We went on talking.

It was as if we thought we lived

in some other world, a world where

when lungs fail, the people learn

some other way to breathe.

Imagine, in need of air, your hands opening up to do the work your lungs have ceased to do.

I would hold my new hands

up into the light. I would place them

against my ears and listen

to the air lacing in and out of the web

between my fingers. Imagine how careful I'd be carrying those new hands

wherever I went.

\title{
Bay Mare in a Second Floor Bedroom
}

In my dream of the last day, a large bay horse followed me into my house and up the stairs. The horse stood quietly behind me as I gathered my possessions: ice-cream bars, cigarettes, 
notebooks. What I was going to do with 6 boxes of chocolate covered ice-creams and 10 packs of cigarettes on the last day, I don't know, and I didn't know what I was going to do with the notebooks, bury them, or take them with me? What is it you're supposed to do on the last day? I was glad the horse was there. I would take one last ride, swing up on her back, no saddle, no bridle, gallop off across the field. For once I knew exactly what I was going to do, and it didn't bother my mother or anyone else that the horse was in the house, floor-boards creasing beneath her hooves.

It was the last day and we all knew it.

I had been at work when it started. We saw missiles lift off out of the hill, American flags draped across each one. None of us knew how much time was left, and none of us knew what to do with the children in our charge. "Excuse us please," we said, "We're sorry, it's time. Put up your chairs, go home, good-bye."

Everyone climbed from the windows. Like small streams of light beneath a blank blue sky, we all ran wherever we needed to run. I went home and the bay mare followed me up the stairs, stood still behind me as I dug through my papers. I went to the window. I saw the ocean lifting itself. The water was black, and for some reason, it made no sound. I saw a friend of mine climb into a small white boat and push out into the waves. She'd told me I shouldn't worry about her any longer.

"Don't bother calling," she had said.

There was no sound, only the white wind cupped in the white sail, the white boat cupped in the curl of a 60 foot wave.

It was the last day. We did what we could. 